\title{
The Mauritians in Sydney
}

\section{Edward Duyker}

The connections between the Indian Ocean island of Mauritius and Sydney span two centuries of trade and immigration.

\section{Early trade}

The very first Mauritian trading expedition to Sydney was undertaken in 1802, during the Peace of Amiens, by Alexandre Josselin Lecorre, who sailed in the Entreprise to Port Jackson in order to sell provisions, arriving on 9 September 1802. (Authorities in Sydney mistakenly registered the Entreprise as the Surprise.)

Governor Philip Gidley King (1758-1808) ever suspicious of French ambitions, flatly refused Lecorre permission to go sealing in Bass Strait, although the intervention of the French explorer Nicolas Baudin caused the governor to relent. However, disaster in the form of a violent storm struck in the Strait, and the Entreprise was wrecked. Lecorre and five other members of the crew drowned.

In the following decades - particularly after the British acquired Mauritius by the Treaty of Paris in 1814 - a major expansion of the Mauritian sugar industry took place, and Sydney soon became an important market for Mauritian sugar. In April 1827, Governor Darling wrote that 'Mauritius ... may be considered as almost exclusively supplying the colony with sugar'. This mercantile relationship also had some implications for communications and immigration. Between 1820 and 1834, for example, the Catholic Church in Australia was officially administered from Mauritius.

Among the earliest free Mauritian immigrants of this period was Geneviève Sornay (1808-1829) wife of Francis Nicholas Rossi (1776-1851), a Frenchman born in Corsica. In May 1825, Rossi replaced D'Arcy Wentworth as Superintendent of the New South Wales police and undertook major organisational changes in the force. He also became one of the first police magistrates in Sydney and was for a time acting controller of customs. Throughout this period Geneviève was his constant companion, but ill-health and the advice of her Sydney doctors decided her to return to Mauritius where she died on 20 April 1829.

Another Mauritian immigrant of this period was Emilie Manton (née Blanchard) who arrived on the Guide in January 1829. She married Frederick Manton, in St Mary’s Cathedral, on 27 July of the same year. Both were later pioneers in Yass and Melbourne, but returned to Sydney where they spent the last four years of their lives and were buried in St Jude’s Church, Randwick, in 1867. 


\section{The convicts}

Between 1817 and 1840, more than 100 convicts left Mauritius for Sydney. Although several convict muster rolls are unavailable, these convicts from Mauritius fell into five basic categories: Mauritian-born slaves or former slaves; Mozambique-, Madagascar- or Bourbon-born slaves or former slaves; Indian (and in some instances Chinese) indentured or former indentured labourers; British military prisoners convicted in Mauritius or transshipped from India; and escaped prisoners from Australia, captured in Mauritius and returned to captivity. There are no details for three of the 41 ships that sailed with convicts from Mauritius to New South Wales, but of 116 convicts accounted for, 62 were British, 31 were Mauritian, 13 were Indian, six were Malagasy, three were from Mozambique and one was from Bourbon (now Réunion).

Very few of these transportees ever returned to Mauritius. Of the non-British convicts, most were young men in their twenties and thirties; most were described as black, brown or coppercoloured; most were born into slavery and few had any surname. Mauritian and Australian convict records indicate that the majority were convicted of stealing. Though some received life sentences, most were transported for between seven and 14 years. Some, who had been slaves on the island, unlike other convicts, had never known freedom.

\section{The sugar industry}

The emergence of a primitive sugar industry in Australia by 1860 coincided with major changes in the Mauritian sugar industry. Many mills on the island were closed down and many skilled 'sugar men' left Mauritius. Some visited Sydney en route to the prospective cane fields in the tropical north of Australia. One was Jerome Thomy de Keating (born in 1826). Between 1857 and 1859 de Keating was co-owner of the La Rosa estate in Mauritius. He arrived in Sydney at the end of January 1865 and between 4 and 19 April wrote a series of letters to the editor of the Sydney Morning Herald on the prospects of large-scale sugar growing in northern New South Wales. The Mitchell Library holds a copy of his 33-page pamphlet entitled A Practical Treatise on the Cultivation of the Sugar Cane and the Manufacture of Sugar Adapted to New South Wales and Other Australian Colonies.

In 1891 there were 263 Mauritians in New South Wales. Their numbers steadily declined after Federation, but some continued to reside in Sydney. Among them was Albert Jules Alexis Giraud (1860-1947), a graduate in agronomy from the Sorbonne, who arrived in Australia in 1879. In 1885 he married Léona Burguez, also from a Mauritian family and aunt of the artist Lloyd Rees (1895-1988). Giraud's home in Mosman was frequented by many Sydney artists and he sat for a portrait by Norman Carter (1875-1963). Both of Giraud's sons fought with the AIF during World War I, and one eventually died as a result of his wounds. 
Another Mauritian-born Sydney resident of this period was George McGuire (1891-1915). In 1910 he joined the 33rd New South Wales Volunteer Infantry Regiment (Irish Rifles) as a 2nd Lieutenant and in 1912 was given command of the Stanmore Company. He served as a captain with the Australian Imperial Force and died in Egypt of wounds suffered at Gallipoli. His father, Duncan Hazlitt McGuire, a former prison warder in Mauritius, had retired with his wife and children to the Sydney suburb of Willoughby in 1902.

\section{The influx}

By the early 1960s, universal suffrage and self-government in Mauritius had undermined the privileges long enjoyed by the island's European population. Complete independence from Britain was regarded with considerable concern by conservative elements. In the minds of the remaining Franco-Mauritian and mixed-race population, independence was equated in a paranoid fashion with Mauritians of south Asian descent 'taking over'. This period also coincided with a weakening of the White Australia policy in Australia and inevitably had repercussions for immigration from Mauritius.

Despite repeated requests, Mauritians going to Australia did not receive assisted passages, as European and British emigrants did. However, a loan scheme was instituted by the Mauritius Commercial Bank, which advanced 90 per cent of the cost of an emigrant's passage at 6 per cent interest over two years and Qantas reduced its prices for Mauritian emigrants in March 1968. By 1981, 10,812 Mauritians had made Australia their home. Most were of mixed racial ancestry. Roughly a third of the Mauritian community in Australia resides in Sydney.

\section{The cultural impact}

Perhaps the most significant aspect of the Mauritian cultural impact in Sydney has been the extent to which Mauritians have participated in, and strengthened, broader French cultural activities. Mauritians are represented in organisations such as the Alliance Française, and over the years have been among the Alliance's office bearers. A number of Mauritians are employed as French language teachers in Sydney. Mauritians have also often capitalised on their 'Frenchness'. Apart from the more distinctive Mauritian cuisine, Mauritian chefs, waiters and restaurateurs are engaged in the preparation of traditional French food.

From the late nineteenth century Mauritians have been involved in French language publishing in Australia. Léon Henry Magrin (1874-1942) secured a position with Le Courrier Australien in 1897 and later purchased the Sydney-based paper. It is now the oldest foreign language publication in Australia. Philippe Tanguy, whose editorial work won praise from Manning Clark, has also been a prominent French language broadcaster in Sydney, mainly with SBS Radio. Bernard Zuel is a music journalist with the Sydney Morning Herald. Actor Odile Leclézio and tenor Henri Wilden are other notable Mauritian-born Sydneysiders. 
The most important Sydney cultural figure with a Mauritian connection was the landscape painter Lloyd Rees (1895-1988). Rees's mother Angèle Burguez was born in Mauritius and came to Australia with her parents, Léon and Elizabeth Burguez, on the Clyde, in May 1878. Angèle helped her daughter Amy run 'Bondo', a guest house on the Great Western Highway, Parramatta, from 1922 until shortly after her son’s first marriage to Dulcie Metcalf in 1926. She was diagnosed with leprosy in 1943 and interned on Peel Island in Moreton Bay until her death from pneumonia on 13 July 1945.

\section{Mauritian organisations}

Mauritian cultural activity in Sydney is focussed on the various Mauritian community organisations. They include La Caravelle; the Australo-Mauritian Association (which has an affiliated sporting club); the Copains Social Club and the Mauritian Chinese Circle of Sydney. There is also a small Rodriguan club in Sydney. (The island of Rodrigues is part of the Republic of Mauritius.) All these organisations arrange social activities and issue newsletters with community news.

Perhaps the most unusual and noble Mauritian group in Sydney is SACIM (Society for Aid to Children Inoperable in Mauritius), which arranges operations in Australia for sick Mauritian children (mainly those suffering from heart disease). Another Mauritian organisation in Sydney is the Laval Charity Group.

There are difficulties in describing Mauritians in Sydney as a single ethnic group, although the vast majority have some French heritage. Regardless of the colour of their skin, they largely share the same religion: Catholicism. While some may not be completely fluent in French, most speak Créole - a language with strong African and Indian influences, but with a basically Frenchderived vocabulary. Increasingly, Mauritians of non-Christian faith (2.5 per cent of the Mauritian community in 1996) and non-French descent have also come to Australia, but the enormous growth in the Mauritian economy in the 1980s, making it the richest country per capita in the African Union, and the political stability of the island as an independent parliamentary republic in the Commonwealth, has greatly reduced the incentive for large numbers of Mauritians to emigrate.

\section{References}

Edward Duyker, Of the Star and the Key: A History of Mauritians in Australia, Australian Mauritian Research Group, Sylvania, 1988

Edward Duyker, 'Coutance and the Voyage of the Adele', Explorations, no 4, March 1987, pp $21-25$ 
Edward Duyker, 'Histoire généalogique: Mauritius and Family History at the National Library', National Library of Australia News, vol IV, no 1, October 1993, pp 4-6

CA Price, Working Papers in Demography No 13: Birthplaces of the Australian Population 1861-1981, Department of Demography, Research School of Social Sciences, Australian National University, Canberra, 1984

F O’Donoghue, ‘Australia’s Connection with Mauritius’, Australasian Catholic Record, January 1976, pp 69-80 